\title{
Dispersal strategies of two species of swimming crab on the continental shelf adjacent to Delaware Bay
}

\author{
C. E. Epifanio \\ College of Marine Studies, University of Delaware, Lewes, Delaware 19958, USA
}

\begin{abstract}
Brachyuran crab larvae were collected on 5 cruises from late July through early September (1981 and 1982) at 3 stations located along a transect extending $30 \mathrm{~km}$ SE from Cape Henlopen at the mouth of Delaware Bay, USA. Samples were taken from the neuston, from $1 \mathrm{~m}$ beneath the surface, from mid-depth, and from $1 \mathrm{~m}$ above the bottom. All stations were dominated by 3 taxa: Callinectes sapidus, Ovalipes ocellatus, and Uca spp. Two of these dominant taxa belong to the same family (Portunidae) and have spawning populations in the estuary or in the sublittoral zone of the adjacent inner shelf. C. sapidus maintained a distribution near the surface at each of the 3 stations. In contrast $O$. ocellatus showed a deeper distribution at stations farther offshore. At the station farthest from the bay mouth $(30 \mathrm{~km}), O$. ocellatus showed a distinct concentration at the thermocline during daylight. At that station, $C$. sapidus larvae maintained a surface distribution regardless of time of day, while $O$. ocellatus showed a pronounced shift up the water column after sunset and a shift down the water column after sunrise. At the offshore station, very few larvae of either species were found below the thermocline regardless of time of day.
\end{abstract}

\section{INTRODUCTION}

Brachyuran crab larvae are a seasonally important constituent of the zooplankton of the inner continental shelf along the east coast of the USA. In the Middle Atlantic Bight (MAB), this assemblage is dominated by indigenous shelf species such as Cancer irroratus and Cancer borealis during late winter and early spring, but estuarine forms such as blue crab Callinectes sapidus and fiddler crabs Uca spp. are pre-eminent during summer and early fall (Dittel \& Epifanio 1982). Once on the continental shelf, the larvae of estuarine species may be dispersed long distances from the parent estuary (Smyth 1980). Subsequent movement back to the estuary appears to occur during the megalopa stage (D. F. Johnson 1985), but despite intensive study, the mechanism for this transport remains unclear (Epifanio et al. 1984, D. R. Johnson 1985). Similarly, the dispersal mechanisms for indigenous shelf larvae are poorly understood. For example there are abundant Lagrangian current data suggesting a general southward flow of surface waters on the outer $\mathrm{MAB}$ shelf during the crab spawning season (Bumpus 1969). The subtidal velocities calculated from these data are sufficient to transport large numbers of $M A B$ larvae south to Cape Hatteras where they would be lost to the Gulf Stream before reaching metamorphosis. Farther inshore, there appears to be a southward current immediately along the coast. This coastal current is driven by the buoyancy of brackish water emanating from the Hudson, Delaware, and Chesapeake estuaries (Garvine 1987) and is also capable of carrying large numbers of larvae away from their parent populations.

While the above studies have shown that southward, subtidal drift occurs year-round on both the outer MAB shelf and immediately along the coast, there are suggestions of a wind-driven, northward flow of surface water in the mid-shelf region during the summer months (D. R. Johnson 1985); near Delaware Bay, this would occur as a band located 15 to $70 \mathrm{~km}$ from shore (Boicourt 1982). This band of northward current on the mid-shelf may act to retain some fraction of larvae in the MAB during summer. In addition, detailed studies of coupled, shelf-estuarine circulation related to Chesapeake Bay (Norcross \& Stanley 1967) and Delaware Bay (Pape \& Garvine 1982) have shown the potential for transport of larvae from the adjacent shelf 


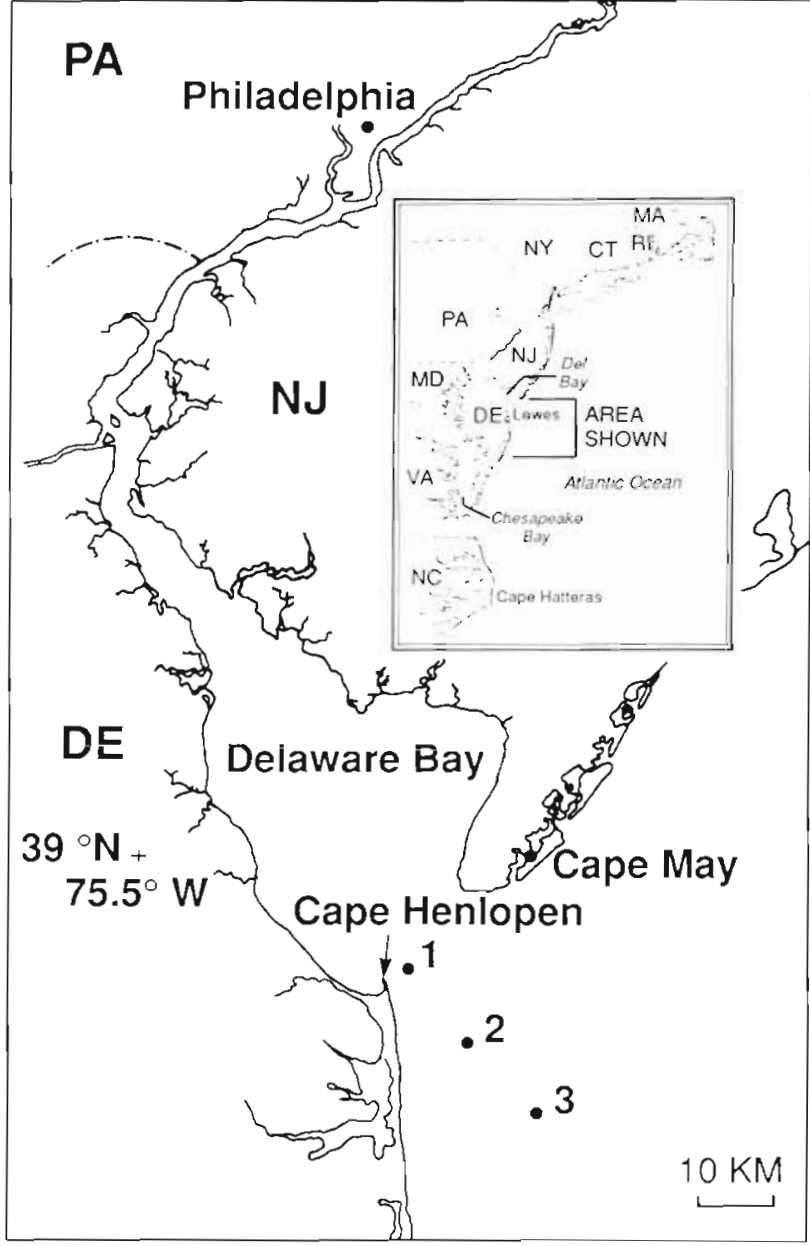

Fig. 1. Location of stations where crab larvae were collected in late summer, 1981 and 1982. Total length of transect is ca $30 \mathrm{~km}$

into these estuaries via landward flow near the bottom, Thus, the direction and rate of movement of a given patch of larvae will depend on both its onshore-offshore position on the continental shelf and its vertical position in the water column.

In this paper I present results of a 2 yr study of the larval distribution of 2 species of portunid (swimming) crab on the inner continental shelf of the MAB and relate that distribution to potential transport by subtidal currents characteristic of the area.

\section{METHODS}

Larvae were collected on 5 cruises from late July through early September (1981 and 1982) at 3 equidistant stations located along a transect extending $30 \mathrm{~km}$ SE from Cape Henlopen at the mouth of Delaware Bay (Fig. 1). Cruises were conducted during daylight and were separated in time by at least 1 wk. At each station, samples were taken from the top $0.3 \mathrm{~m}$, from $1 \mathrm{~m}$ beneath the surface, and from $1 \mathrm{~m}$ above the bottom. Mid-depth samples were also taken at the 2 offshore stations. The mid-depth sample at $\operatorname{Stn} 3$ was always collected in the thermocline. Samples were taken with a specially designed neuston sampler (Epifanio et al. 1984) or with a $0.3 \mathrm{~m}$ Clarke-Bumpus Sampler rigged with a $243 \mu \mathrm{m}$ mesh net; all tows were $10 \mathrm{~min}$ in duration. Before sampling at each station, salinity and temperature were measured every $5 \mathrm{~m}$ from surface to bottom with a Beckman RS-5 CST meter; depth at the 3 stations ranged from 20 to $25 \mathrm{~m}$. In addition to the daylight sampling, larvae were collected at Stn 3 every $3 \mathrm{~h}$ from sunset to sunrise on 16 to 17 August 1982. Sampling protocol was exactly as described above.

Samples from all collections were preserved on board in $4 \%$ formaldehyde in seawater. After a minimum of $1 \mathrm{wk}$ in formaldehyde, samples were transferred to $70 \%$ ethanol. Samples were subdivided with a Folsom Plankton Splitter (Dittel \& Epifanio 1984), and one randomly chosen subsample was analyzed for each collection. Larvae were identified to taxon and stage using a key to the decapod larvae of the region (Sandifer 1972).

\section{RESULTS}

\section{Hydrography}

The water column at Stn 1 (bay mouth) and Stn 2 (15 km offshore) was usually well mixed with only slight decreases in temperature from surface to bottom (Fig. 2). There was occasional stratification at Stn 2, but a distinct thermocline was rarely observed. At Stn 3, a thermocline always occurred between 10 and $15 \mathrm{~m}$, and temperatures below the thermocline were as low as $11^{\circ} \mathrm{C}$.

\section{Daylight sampling}

More than 100000 brachyuran larvae were collected during 1981 and 1982. Of the 13 taxa collected, Callinectes sapidus, lady crab Ovalipes ocellatus, and Uca spp. were most abundant. The other 10 species combined did not constitute more than $25 \%$ of the total number of larvae collected at any of the stations. $C$. sapidus, $O$. ocellatus, and Uca spp. constituted more than $95 \%$ of the total number of larvae collected at the most offshore station (Fig. 3). However, the data for UCa spp. were presented in a previous paper (Epifanio et al. 1988), and the present analysis is restricted to $C$. sapidus and $O$. ocellatus. 
Fig. 2. Typical late-summer temperature profiles at 3 stations extending $30 \mathrm{~km}$ southeast from Strn 1 in the mouth of Delaware Bay, USA

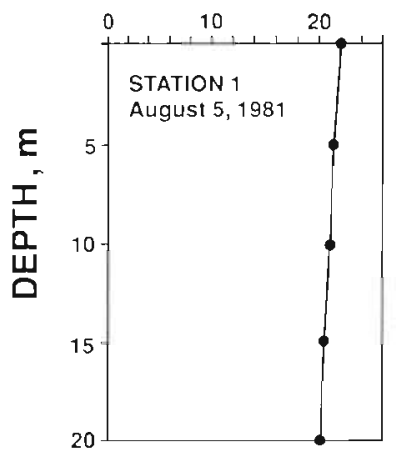

TEMPERATURE, ${ }^{\circ} \mathrm{C}$
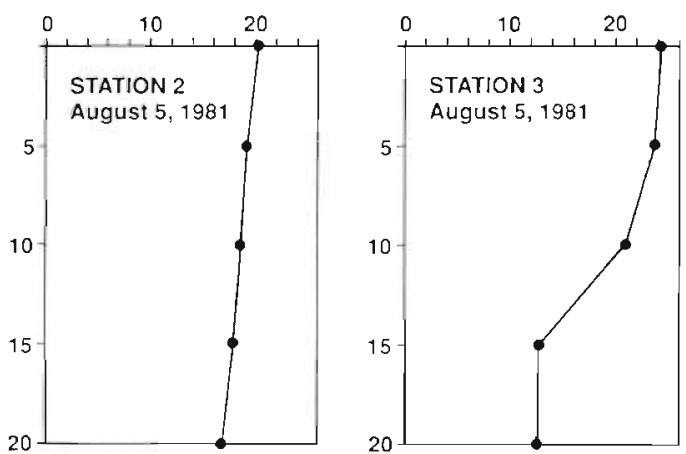

For both of these species, zoea Stage I was predominant at Stn 1, and the proportion of advanced larval stages increased with distance from shore. At each



Fig. 3. Abundance of crab larvae along a transect extending $30 \mathrm{~km}$ southeast from Stn 1 in the mouth of Delaware Bay, USA. Values are percentages of the total number of larvae collected at each station during weekly sampling from late July through mid-September in 1981 and 1982. C. sap.: Callinectes sapidus; O. oval.: Ovalipes ocellatus; Uca spp.: Uca minax and Uca pugnax; Other: Cancer irroratus, Libinia spp., Pinnotheres spp., Pinnixia spp., and Sesarma reticulatum station Kruskal-Wallace analysis showed significant (alpha $=0.05$ ) differences in the percentage abundance at each depth for both Callinectes sapidus and Ovalipes ocellatus, i.e. neither species was uniformly distributed in the water column regardless of station. Graphical analysis showed that $C$. sapidus maintained a distribution near the surface at each of the 3 stations (Fig. 4). In contrast $O$. ocellatus was common at the surface at $\operatorname{Stn} 1$. but took a deeper position farther offshore. At Stn 2, the combined abundance at mid-depth and near the bottom was ca $85 \%$. At Stn 3, O. ocellatus showed a distinct concentration at the thermocline (mean percentage abundance $=65 \%$ ), but less than $10 \%$ of the larvae were collected below the thermocline.

\section{Diel sampling}

At $\operatorname{Stn} 3$, Callinectes sapidus larvae maintained a surface distribution throughout the night, while Ovalipes ocellatus showed a pronounced shift up the water column after sunset and a shift down the water column after sunrise (Fig. 5). Very few larvae of either species were found below the thermocline regardless of time of day.

\section{DISCUSSION}

Results of this $2 \mathrm{yr}$ investigation show that the latesummer assemblage of crab larvae on the inner continental shelf off Delaware Bay is dominated by 3 taxa: Callinectes sapidus, Ovalipes ocellatus, and UCa spp. This was less pronounced within $15 \mathrm{~km}$ of the bay mouth where several species of mud crab (Xanthidae) larvae were common, but the numerical dominance was almost complete at a station $30 \mathrm{~km}$ offshore. Among these dominant taxa, C. sapidus and $O$. ocellatus belong to the same family (Portunidae) and have spawning populations in the estuary or in the sublittoral zone of the adjacent continental shelf. However, results of this and other investigations indicate that zoeal develop- 


\section{PERCENTAGE ABUNDANCE}
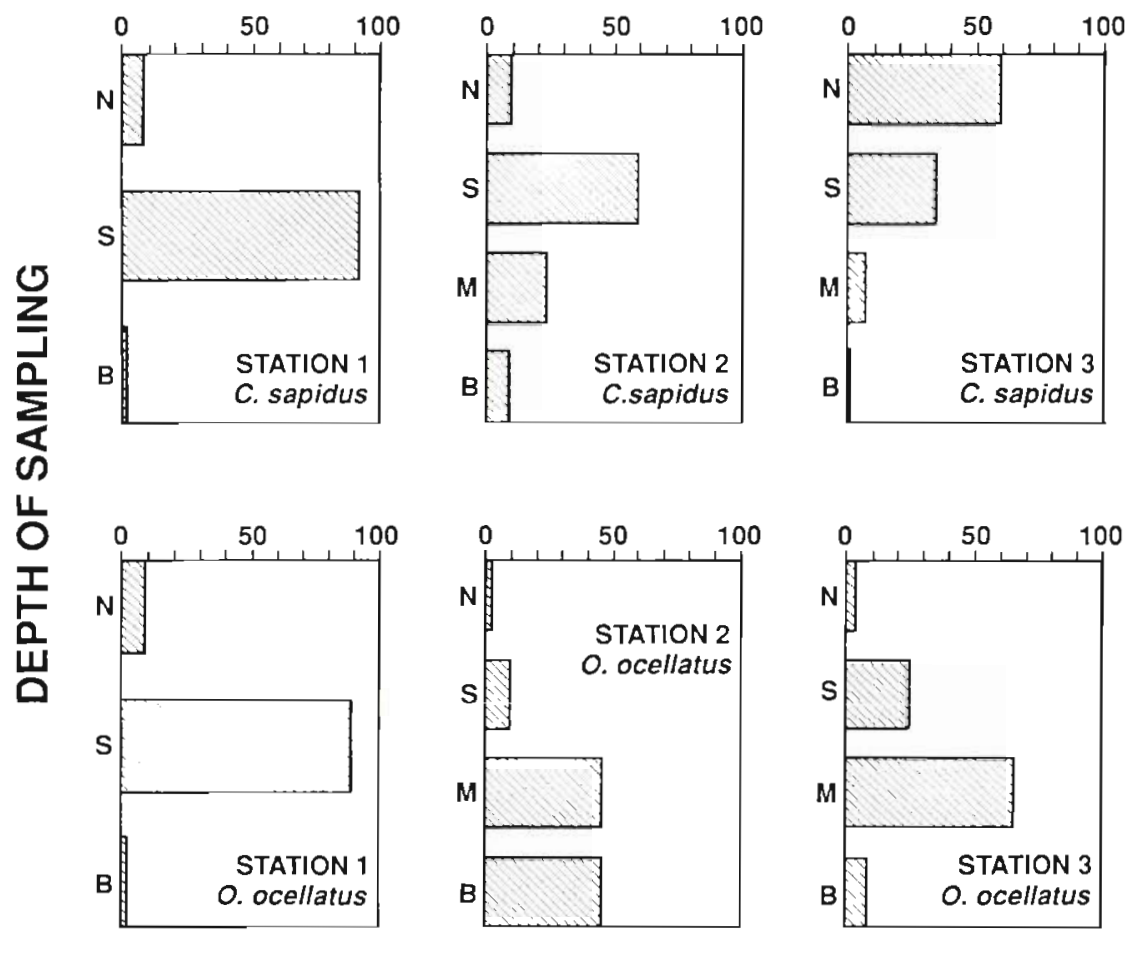

Fig. 4. Callinectes sapidus, Ovalipes ocellatus. Vertical distribution of zoea larvae along a transect extending $30 \mathrm{~km}$ southeast from Stn 1 in the mouth of Delaware Bay, USA. Water depth was ca $20 \mathrm{~m}$ at each station. Values are means of weekly cruises during late July through mid-September in 1981 and 1982. N: neuston; $S$ : surface; $M$ : mid-depth; $T$ : thermocline; B: bottom

\section{PERCENTAGE ABUNDANCE}

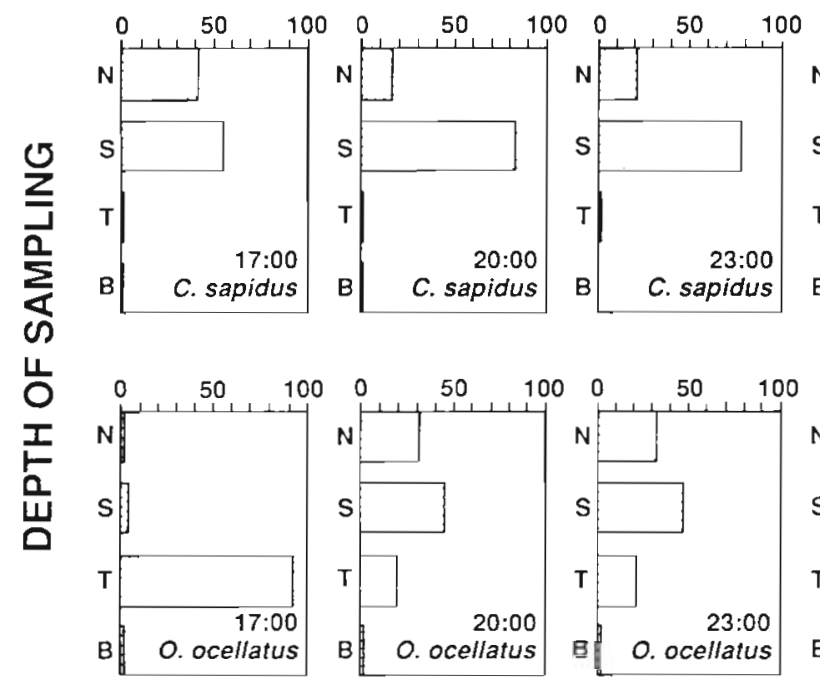

ment for both species occurs in the open waters of the mid- to inner shelf. Thus, for stable populations of $C$. sapidus and $O$. ocellatus to exist in the MAB, zoeae must avoid southward transport out of the MAB and megalopae must be carried toward the coast for settlement in immediate nearshore or estuarine waters. Nevertheless, larvae of the 2 species showed different vertical positions in the water column and were presumably subjected to different advective regimes.


Fig. 5. Callinectes sapidus, Ovalipes ocellatus. Vertical distribution of zoea larvae from late afternoon through early morning at Stn 3, ca $30 \mathrm{~km}$ southeast of Cape Henlopen at the mouth of Delaware Bay, USA. Sunset $=18: 55 \mathrm{~h}$. Sunrise $=05: 13 \mathrm{~h}$ Depth $=20 \mathrm{~m}$. N: neuston; $\mathrm{S}$ : surface; $T$ : thermocline; $B$ : bottom. Time is Eastern Standard Time

Callinectes sapidus zoeae maintained a position high in the water column regardless of stage of development or time of day. Thus the movement of C. sapidus zoeae must have been determined by surface currents. Whyle Lagrangian studies of circulation off Delaware Bay indicate a general southward movement of surface water during late summer (Bumpus 1969, Pape \& Garvine 1982), our unpublished current meter measurements (1983 and 1984) have shown a northward, subti- 
dal flow of surface water just offshore of the Delaware Bay plume in late summer. This current provides a mechanism for northward transport. Thus mixing between the Delaware Bay plume and this northward flowing current would lead to retention of surfacedwelling species such $C$. sapidus. However in the absence of persistent wind, subtidal surface flow in the $M A B$ would be southward during late summer (Beardsley et al. 1976); thus the effectiveness of the proposed retentive mechanism is a function of the strength and duration of northward directed winds over the inner continental shelf during the spawning season.

In contrast, Ovalipes ocellatus zoeae showed a surface distribution only in the mouth of Delaware Bay where larvae were predominantly zoea Stage I. At Stn 2, 0 . ocellatus were generally older and were positioned deeper in the water column. During daylight hours, large numbers of zoeae were collected from mid-depth all the way to the bottom, thus placing the larvae in onshore-flowing water associated with the estuarine circulation of Delaware Bay.

At Stn 3, Ovalipes ocellatus larvae were deep in the water column during daylight but did not extend all the way to the bottom. Instead, the larvae accumulated at the thermocline until sunset when they appeared to migrate to the surface, where they remained until sunrise. These zoeae would have been carried to the north along with wind-driven surface waters during the night. But their transport during daylight is less certain as the magnitude and direction of currents at the thermocline have not been measured in the MAB. Nevertheless, subtidal flow below the thermocline at Stn 3 is strongly toward Delaware Bay (Pape \& Garvine 1982), and it is probable that flow at the thermocline is landward as well. Thus, a net onshore displacement of vertically migrating larvae is indicated.

Thus in spite of a close taxonomic relationship and a common spawning area for the adult forms, Callinectes sapidus and Ovalipes ocellatus show very different dispersal strategies. C. sapidus zoeae remain near the surface throughout the 5 to 6 wk required to complete their 8 zoeal stages (McConaugha et al. 1983). There, they are dependent on wind-driven surface currents to retain them in the vicinity of the parent estuary. Because there is a southward flow of MAB surface water in the absence of wind, the strength and persistence of northward winds during the spawning season must be prime factors controlling the retention of zoeae near estuaries suitable for juvenile existence. Indeed, modeling studies have shown some correlation between northward winds during a spawning season and blue-crab fishery yields 2 yr later (Johnson et al. 1984).

The dispersal strategy of Ovalipes ocellatus is more similar to that of $U c a$ spp. as only the early zoeal stages are carried southward in surface water flowing out of
Delaware Bay (Epifanio et al. 1988). In both O. ocellatus and $U_{c a}$ spp., more advanced zoeal stages appear to take up a position deeper in the water column, thereby facilitating subtidal advection to the nearshore habitat. This is further complicated by an apparent diurnal migration that brings $O$. ocellatus zoeae to the surface at night. While this migratory pattern may have evolved in response to selective factors quite separate from dispersal, $O$. ocellatus zoeae undertaking the migration are exposed to surface currents for ca $40 \%$ of each latesummer day. Regardless, the combined effect of transport both at the surface and deeper in the water column appears to result in movement of the zoeae toward the parent estuary. Because the onshore movement of deep waters in this region is associated with the estuarine circulation of Delaware Bay, some variation in strength would be expected as a function of differences in freshwater flow into the estuary from the Delaware River. However variations in the duration and magnitude of this deep flow must be small compared to variations in wind-driven surface flow (Pape \& Garvine 1982). Thus, O. ocellatus zoeae should show less variation than $C$. sapidus zoeae in their retention in nearshore waters. Available data corroborate this idea, as results of several larval surveys indicate that $O$. ocellatus zoeae are very rare outside the nearshore region, while $C$. sapidus zoeae are common over the outer continental shelf (Nichols \& Keney 1963, Smyth 1980).

Acknowledgements. This research was sponsored by NOAA Office of Sea Grant, Department of Commerce, under Grant No. NA.85AA-D-SG033 (Project R/M-4). I thank Meo Curtis, Mona DeVries, Nancy O'Connor, Christopher Valenti, and Capt. Thomas White for assistance in collection and analysis of plankton samples. My colleague Richard W. Garvine provided insight into the physical ocearography of the study area.

\section{LITERATURE CITED}

Beardsley, R. C., Boicourt, W. C., Hansen, D. V. (1976). Physical oceanography of the Middle Atlantic Bight. Limnol. Oceanogr. Spec. Symp. 2: 20-34

Boicourt, W. C. (1982). Estuarine larval retention mechanisms on two scales. In: Kennedy, V. (ed.) Estuarine comparisons. Academic Press, New York, p. 445-457

Bumpus, D. R. (1969), Reversals in the surface drift in the Middle Atlantic Bight area. Deep Sea Res. Suppl. 16: 17-23

Dittel, A. I., Epifanio, C. E. (1982). Seasonal abundance and vertical distribution of crab in Delaware Bay. Estuaries 5: $197-202$

Epifanio, C. E., Valenti, C. C., Pembroke, A. E. (1984). Dispersal and recruitment of blue crab larvae in the Delaware Bay, USA. Estuar. coast. Shelf. Sci. 18: 1-12

Epifanio, C. E., Little, K. T., Rowe, P. M. (1988). Dispersal and recruitment of fiddler crab larvae in the Delaware River estuary. Mar. Ecol. Prog. Ser. 43: 181-188

Garvine, R. W. (1987). Observations of the coupled circulation between Delaware Bay and inner continental shelf. EOS 68: 1733 
Johnson, D. F. (1985). The distribution of brachyuran crustacean megalopae in the waters of the York River, lower Chesapeake Bay, and adjacent shelf: implications for recruitment. Estuar. coast. Shelf Sci. 20: 693-705

Johnson, D. R. (1985). Wind-forced dispersion of blue crab larvae in the Middle Atlantic Bight. Cont. Shelf Res. 4: $733-745$

Johnson, D. R., Hester, B. S., McConaugha, J. R. (1984). Studies of a wind mechanism influencing the recruitment of blue crabs in the Middle Atlantic Bight. Cont. Shelf Res. 3: $425-437$

McConaugha, J. R., Johnson, D. F., Provenzano, A. J., Maris, R C. (1983). Seasonal distribution of larvae of Callinectes sapidus (Crustacea: Decapoda) in the waters adjacent to Chesapeake Bay. J. Crust. Biol. 3: 582-591

Nichols, P. R., Keney, P. M. (1963). Crab larvae (Callinectes), in plankton collections from cruises of $\mathrm{M} / \mathrm{V}$ Theodore
N. Gill, South Atlantic Coast of the United States, 1953-54. U.S. Fish Wildl. Serv., Spec. Sci. Rep. Fish. 448: 1-14

Norcross, J. J., Stanley, E. M. (1967). Inferred surface and bottom drift. In: Harrison, W., Norcross, T T., Pore, N. A., Stanley, E. M. (eds.) Circulation of shelf waters off the Chesapeake Bight. Environmental Sciences Services Administration Professional Paper 3, US Dept of Commerce, p. 11-42

Pape, E. H. III, Garvine, R. W. (1982). The subtidal circulation in Delaware Bay and adjacent shelf waters. J. geophys. Res. 87: 7955-7970

Sandifer, P. A. (1972). Morphology and ecology of Chesapeake Bay decapod crustacean larvae. Doctoral dissertation, University of Virginia, Charlottesville

Smyth, P. O. (1980). Callinectes (Decapoda: Portunidae) larvae in the Middle Atlantic Bight, 1975-1977. Fish. Bull. U.S. 78: $251-265$

This article was submitted to the editor; it was accepted for printing on September 8, 1988 